\title{
IMPACT OF WALKING SPEED AND SLOPE OF THE GROUND ON AXIAL FORCE OF POLES IN NORDIC WALKING
}

\author{
Martin Pšurný*, Miroslav Janura, Jakub Krejčí, Aleš Jakubec
}

Faculty of Physical Culture, Palacký University, Olomouc, Czech Republic

Submitted in July, 2013

\begin{abstract}
BACKGROUND: Nordic walking (NW), due to its attractiveness and convenience of equipment, is becoming more popular and utilised in the areas of sports, recreation and physiotherapy. Some of its impacts on load to the body have not yet been sufficiently explored.

OBJECTIVE: The objective of the study was to determine the impact of walking speed and slope of the ground on the magnitude of axial forces, transferred to the poles by upper extremities during NW.

METHODS: The study was participated in by 17 healthy subjects, aged $25.9 \pm 3.6$ years, who went through 12 independent measurements on a treadmill in various speeds $\left(6.0 ; 6.6 ; 7.2\right.$ and $\left.7.8 \mathrm{~km} \cdot \mathrm{h}^{-1}\right)$ and slopes $(0 ; 5$ and $7.5 \%)$. These measurements provided us with values of basic spatiotemporal variables, characterizing NW performance and force variables, acting on the poles.

RESULTS: Increased walking speed led to increase in cycle frequency $(p<.001)$ and increase in peak poling force and average poling force $(p<.001)$. Poling time reduced with increasing speed $(p<.001)$. Increase in slope of ground had no significant impact on the magnitude of time and dynamic variables.

CONCLUSIONS: Increased walking speed during NW increases the force, generated by the upper extremities on the poles. During NW it is possible to prefer walking speed rather than to change the slope of the ground for those patients, who are indicated to strengthen upper extremities.
\end{abstract}

Keywords: Uphill walking, upper extremities, biomechanics, tensometric sensor.

\section{INTRODUCTION}

Recently, the interest in NW has been on the rise. The advantage of this physical activity is that it is a simple and natural movement, based on natural walking, similar to basic human locomotion. NW as a form of exercise is, due to its attractiveness, becoming increasingly more utilised in the areas of sports, recreation, tourism and physiotherapy (Morgulec-Adamowicz, Marszałek, \& Jagustyn, 2011).

Comparative studies dealing with biomechanical analysis of NW and normal walking often come to different conclusions. Some of these studies are more inclined towards the opinion that the load on lower extremities is lower when using the poles then in normal walking (Bohne, \& Abendroth-Smith, 2007; Foissac, Berthollet, Seux, \& Belli, 2008; Knight \& Caldwell, 2000; Riegrová, 2007; Schwameder, Roithner, Müller, Niessen, \& Raschner, 1999; Willson, Torry, Decker,

\footnotetext{
* Address for correspondence: Martin Pšurný, Department of Natural Sciences in Kinanthropology, Faculty of Physical Culture, Palacký University, tř. Míru 115, 77111 Olomouc, Czech Republic. E-mail: martin.psurny@gmail.com
}

Kernozek, \& Steadman, 2001). Other authors found that to the contrary, using the poles increased the load on the lower extremities (Hagen, Hennig, \& Stieldorf, 2011; Stief et al., 2008) or that using the poles does not reduce the load on the lower extremities (Hansen, Henriksen, Larsen, \& Alkjaer, 2008). In other outputs, results do not show a clear trend. While the magnitude of reaction force was higher in heel strike when compared with normal walking, it was reduced in the push off (Hagen et al., 2011; Kleindienst, Michel, Schwarz, \& Krabbe, 2006; Stief et al., 2008). The differences in walking speed and slope of the ground of these studies could cause the differences in the load on the lower extremities. Proper technique also plays an important role in NW, as the reaction of the body segments depends on it (Hagen et al., 2011; Hansen et al., 2008; Schiffer, Knicker, Dannohl, \& Strüder, 2009). The number of outputs dealing with NW is high. However, we found only 2 studies dealing with the axial forces, transferred to the poles by upper extremities during NW.

The impact of surface (in horizontal plane) on which the subjects moved (concrete, grass, artificial athletics track) and on dynamic variables of the upper extremities was explored by Schiffer et al. (2009). They found that the type of surface has no impact on 
impulse of poling force, and that using the poles leads to inefficient increase in effort, rather than helping to move forward.

Schiffer, Knicker, Montanarella, and Strüder (2011) investigated how the weight of the poles impact of the upper extremities. They came to the conclusion that poles of a higher weight have no impact on energy kinetic variables expenditure, but only increase muscle activity. It is for this reason that the authors do not recommend using heavier poles for NW. To detect the magnitude of biomechanical load, which is then reflected to physiological load, the magnitude of axial forces, transferred to the poles by upper extremities during NW, needs to be identified. The objective of the study was to determine the impact of walking speed and slope of the ground on the spatiotemporal variables and the magnitude of axial forces, transferred to the poles by upper extremities during NW.

\section{METHODS}

\section{Measured group}

The research group consisted of 17 healthy subjects (10 men and 7 women) aged $25.9 \pm 3.6$ years, with average mass $70.6 \pm 11.5 \mathrm{~kg}$ and height $1.76 \pm 0.072 \mathrm{~m}$, who had no experience with NW prior to commencing the research. They voluntarily participated in the study after they provided their written consent. The study was approved by the Ethical Committee of the Faculty of Physical Culture at Palacký University in Olomouc.

\section{Instrumentation}

To measure axial forces generated by the upper extremity on a pole during the support phase, the MPAF system (Department of Natural Sciences in Kinanthropology, Czech Republic) was used. This system consists of a tensometric force sensor, electronic evaluation unit and personal computer with operating software. The measuring range of the sensor is $\pm 1000 \mathrm{~N}$. The system can be calibrated using a set of calibrated weights, in accordance with internal calibration procedure. Sensors' accuracy is $S D=0.5 \mathrm{~N}$. The data acquired from the force transducers contained the forces of the right and left poles that were tested at $1000 \mathrm{~Hz}$ frequency. The data were levelled by a digital lowpass filter with a passband of $0-100 \mathrm{~Hz}$ and stopband of 200-500 Hz. The filtration cut the high frequency signal component that carried no useful information (Krejčí, Jakubec, Pšurný, \& Janura, in press). The sensor was inserted by cutting the pole (BIRKI, Czech Republic), shortening it by the length of the sensor and fitting it with screw connections. Tensometric force sensor was inserted in the pole as close to the handle as possible in order to achieve maximum possible elimination of increasing the weight of the end of the pole. The screw con- nections enable changing the bottom part of the pole and hence selecting optimum length of the pole for a given subject. Seven pole lengths ranging from 105 to $135 \mathrm{~cm}$ by step $5 \mathrm{~cm}$ were available so each subject could choose preferred pole length.

\section{Experimental procedure and protocols}

Before measuring began, subjects were introduced to basic principles of NW. Practical training in two one hour lectures, led by a NW lecturer followed. Furthermore, subjects were introduced to walking on an ergometer LODE Valiant (Lode, B. V. Medical Technology, Groningen, Netherlands). The length of the poles for each subject was determined to $68 \%$ of his/her total body height (Hansen \& Smith, 2009).

During the experiment itself, the impact of two external factors (slope of the ground and walking speed) on dynamic variables acting on the poles was monitored. Each of the subjects went through 12 trials (maximum 1 to 2 trials in one day, with sufficient rest interval) with slope of the ground $0 ; 5$ and $7.5 \%$ and the walking speed $6.0 ; 6.6 ; 7.2$ and $7.8 \mathrm{~km} \cdot \mathrm{h}^{-1}$. Each trial consisted of a 5 minute warm-up on a treadmill, where walking speed and slope of the ground corresponded with the slope and speed, which were subsequently measured (Figure 1). Measuring for a period of 10 minutes followed. The sequence of individual being measured was random.

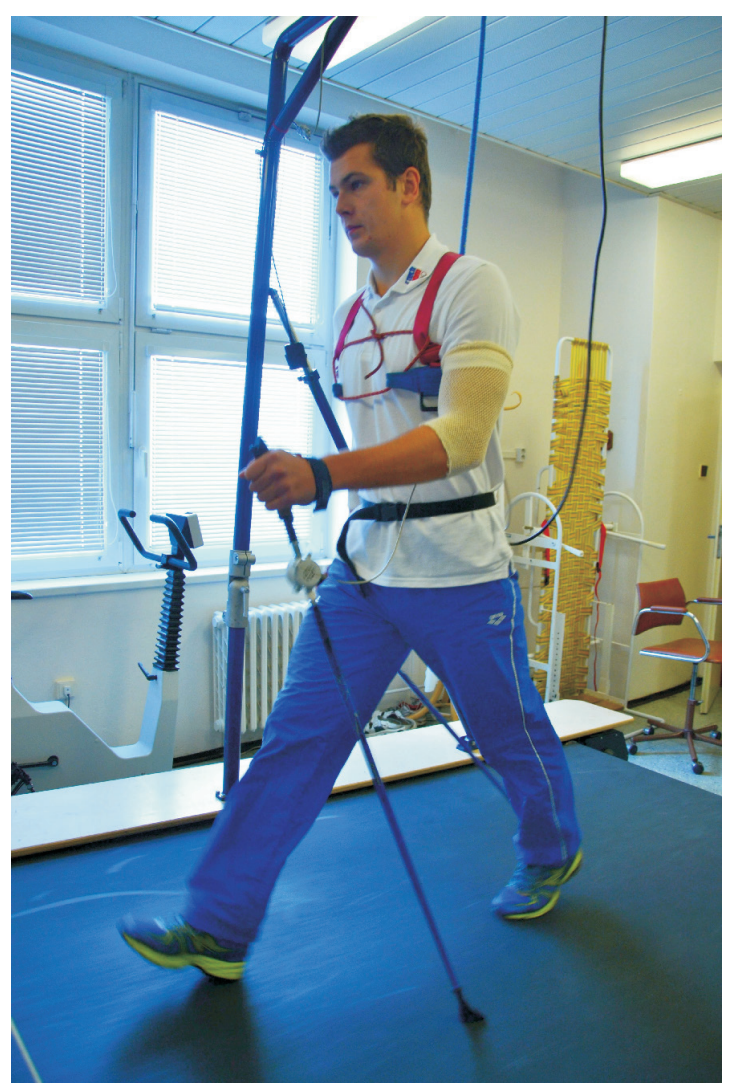

Figure 1. Experimental procedure 


\section{Measured variables}

One cycle was defined as the period from the start of the pole ground contact to the start of the subsequent pole ground contact. Each cycle was divided into a poling phase and a recovery phase. The poling phase was determined as a phase in which measured force is greater to $0 \mathrm{~N}$. If poling phase did not meet criteria (peak force greater to $5 \mathrm{~N}$, duration greater to $0.1 \mathrm{~s}$ ), the entire cycle was dropped. Variables were calculated from force-time curve as follows - cycle time $(\mathrm{CT})$, poling time (PT), relative poling time $(\mathrm{RPT}=100 \% \cdot \mathrm{PT} / \mathrm{CT})$, cycle frequency $(\mathrm{CF}=1 / \mathrm{CT})$, peak poling force (PPF - maximal force achieved during poling phase), impulse of poling force (IPF - integration of the force-time curve during poling phase), average poling force $(\mathrm{APF}=\mathrm{IPF} / \mathrm{PT})$, and average cycle poling force $(\mathrm{ACPF}=\mathrm{IPF} / \mathrm{CT})($ Krejčí, Jakubec, Pšurný, \& Janura, in press).

\section{Data analysis}

Acquired data were processed using Statistica (version 10.0, Stat-Soft, Inc., Tulsa, OK). Values of individual variables from each step cycle, acquired during $10 \mathrm{~min}$ utes of measuring, were averaged for each subject.

All variables from the right and left pole were averaged for each cycle. Variables were averaged over about lasting 10 minutes for each subject. The data were analyzed using a two-way (velocity and slope) ANOVA. A Scheffe's test was used for all post-hoc pair-wise comparisons. The desired power of the study was 0.8 for the differences in the variables noted in this study. Differences with significance level of $p<.05$ were identified as statistically significant. To determine effect size, the value of partial $\eta^{2}(<.01-$ small effect size; $<.06$ - medium effect size; $<.14-$ large effect size) was used.

\section{RESULTS}

Basic statistical characteristics of measured variables and comparison of their differences upon different walking speed and slope of the ground are stated in Table 1.

Increase in walking speed in all cases significantly impacted cycle frequency, which increased $(p<.001$; $\left.F=83.94 ; \eta^{2}=.567\right)$. Poling time value reduced with increase in walking speed $(p<.001 ; F=43.17$; $\left.\eta^{2}=.473\right)$. The highest increase in cycle frequency (by $20.6 \%$ ) occurred at $7.5 \%$ slope after increase in speed from $6.0 \mathrm{~km} \cdot \mathrm{h}^{-1}$ to $7.8 \mathrm{~km} \cdot \mathrm{h}^{-1} \quad(p<.001)$ (Figure 2). The greatest reduction in poling time (by $18.4 \%$ ) was recorded at $5 \%$ slope, after increase in speed from $6.0 \mathrm{~km} \cdot \mathrm{h}^{-1}$ to $7.8 \mathrm{~km} \cdot \mathrm{h}^{-1}(p<.001)$.

Increase in walking speed significantly impacted peak poling force $\left(p<.001 ; F=11.57 ; \eta^{2}=.153\right)$.
The highest increase in poling force (by $46.4 \%$ ) was measured at $7.5 \%$ slope after increase in speed from $6.0 \mathrm{~km} \cdot \mathrm{h}^{-1}$ to $7.8 \mathrm{~km} \cdot \mathrm{h}^{-1}(p<.001)$ (Figure 3). The greatest increase in average poling force (by $30.7 \%$ ) occurred at $0 \%$ slope, after increasing velocity from $6.0 \mathrm{~km} \cdot \mathrm{h}^{-1}$ to $7.8 \mathrm{~km} \cdot \mathrm{h}^{-1}(p<.01)$.

Impact of speed on other variables such as relative poling time, average cycle poling force and impulse of poling force was not found.

Impact of slope of ground on all of the above stated variables was statistically insignificant. In the order of the values measured for each walking speed and different slope of the ground, there is a significant difference in Cycle frequency $\left(p<.01 ; F=3.13 ; \eta^{2}=.128\right)$ (Figure 2).

\section{DISCUSSION}

NW can be used by active athletes as part of their fitness training and also by patients during physiotherapy (Jakubec et al., 2009; Kocur, Deskur-Śmielecka, Wilk, \& Dylewicz, 2009; Morgulec-Adamowicz, Marszałek, \& Jagustyn, 2011). Apart from load to cardiovascular system, articular and muscular system must also be considered. This also applies to load on upper extremities, which play a key role in NW.

A study by Willson et al. (2001) describes an increase in walking speed, when poles are used, as compared to normal walking. It is clear from this perspective that propulsion of upper extremities is actively engaged in forward motion. According to authors Hagen et al. (2011), increased walking speed upon horizontal position of the ground leads to enhance of ground reaction forces of lower extremities in the phase of initial contact with the ground. This phenomenon can have a negative impact on the musculoskeletal system in the elderly, people suffering from obesity or individuals with orthopaedic problems in their lower extremities. From this perspective, it is important to pay attention to force variables of upper extremities, which can have a positive impact on the cardiopulmonary system but on the other hand increase the load on lower extremities.

Our study is a part of more comprehensive research, which was focused on the impact of changing external conditions on biomechanical and physiological variables during NW. We assumed that the increase in walking speed and the slope of the ground would increase the demands on the NW performance thus the increase the requirements of axial forces, transferred to the poles by upper extremities during NW.

\section{Impact of walking speed}

Cycle frequency of human walking is spontaneously selected in such manner so as to minimize energy ex- 
Table 1

Basic statistical characteristics of measured variables $(N=17)$

\begin{tabular}{|c|c|c|c|c|c|}
\hline \multirow[b]{2}{*}{ Variable } & \multirow[b]{2}{*}{ Slope } & \multicolumn{4}{|c|}{ Speed $(M \pm S D)$} \\
\hline & & $6.0 \mathrm{~km} \cdot \mathrm{h}^{-1}$ & $6.6 \mathrm{~km} \cdot \mathrm{h}^{-1}$ & $7.2 \mathrm{~km} \cdot \mathrm{h}^{-1}$ & $7.8 \mathrm{~km} \cdot \mathrm{h}^{-1}$ \\
\hline \multirow{3}{*}{$\mathrm{CF}[\mathrm{Hz}]$} & $0 \%$ & $0.91 \pm 0.058$ & $0.96 \pm 0.052$ & $1.01 \pm 0.056$ & $1.06 \pm 0.063$ \\
\hline & $5 \%$ & $0.90 \pm 0.053$ & $0.95 \pm 0.059$ & $1.01 \pm 0.051$ & $1.08 \pm 0.064$ \\
\hline & $7.5 \%$ & $0.90 \pm 0.055$ & $0.96 \pm 0.052$ & $1.02 \pm 0.051$ & $1.08 \pm 0.067$ \\
\hline \multirow{3}{*}{ PT [s] } & $0 \%$ & $0.45 \pm 0.101$ & $0.42 \pm 0.078$ & $0.40 \pm 0.068$ & $0.39 \pm 0.073$ \\
\hline & $5 \%$ & $0.47 \pm 0.078$ & $0.44 \pm 0.070$ & $0.42 \pm 0.061$ & $0.38 \pm 0.068$ \\
\hline & $7.5 \%$ & $0.47 \pm 0.094$ & $0.45 \pm 0.063$ & $0.40 \pm 0.057$ & $0.39 \pm 0.053$ \\
\hline \multirow{3}{*}{ RPT [\%] } & $0 \%$ & $40.8 \pm 8.26$ & $39.8 \pm 6.68$ & $39.8 \pm 5.55$ & $40.8 \pm 6.27$ \\
\hline & $5 \%$ & $41.7 \pm 5.66$ & $41.3 \pm 5.40$ & $42.9 \pm 5.17$ & $40.6 \pm 5.55$ \\
\hline & $7.5 \%$ & $42.1 \pm 6.64$ & $42.8 \pm 5.04$ & $40.7 \pm 4.70$ & $41.6 \pm 4.55$ \\
\hline \multirow{3}{*}{$\mathrm{PPF}[\mathrm{N}]$} & $0 \%$ & $38.7 \pm 15.30$ & $42.4 \pm 16.85$ & $50.9 \pm 20.31$ & $56.5 \pm 16.95$ \\
\hline & $5 \%$ & $42.8 \pm 16.57$ & $47.9 \pm 16.33$ & $53.8 \pm 18.61$ & $62.4 \pm 19.34$ \\
\hline & $7.5 \%$ & $44.5 \pm 16.58$ & $50.4 \pm 16.44$ & $55.1 \pm 16.63$ & $65.1 \pm 19.92$ \\
\hline \multirow{3}{*}{$\operatorname{APF}[\mathrm{N}]$} & $0 \%$ & $22.0 \pm 8.70$ & $23.2 \pm 7.55$ & $25.6 \pm 7.59$ & $28.2 \pm 8.95$ \\
\hline & $5 \%$ & $19.2 \pm 7.64$ & $20.7 \pm 8.91$ & $23.4 \pm 10.26$ & $25.1 \pm 8.32$ \\
\hline & $7.5 \%$ & $22.7 \pm 8.50$ & $24.3 \pm 8.17$ & $25.9 \pm 8.41$ & $28.9 \pm 9.03$ \\
\hline \multirow{3}{*}{$\mathrm{ACPF}[\mathrm{N}]$} & $0 \%$ & $9.49 \pm 4.57$ & $9.72 \pm 3.65$ & $11.26 \pm 4.14$ & $11.81 \pm 4.75$ \\
\hline & $5 \%$ & $8.27 \pm 4.13$ & $8.60 \pm 4.53$ & $9.68 \pm 5.20$ & $10.50 \pm 4.36$ \\
\hline & $7.5 \%$ & $9.89 \pm 4.69$ & $10.71 \pm 4.46$ & $10.75 \pm 4.02$ & $12.27 \pm 4.47$ \\
\hline \multirow{3}{*}{$\operatorname{IPF}[\mathrm{N} \cdot \mathrm{s}]$} & $0 \%$ & $9.22 \pm 4.95$ & $9.12 \pm 5.31$ & $9.80 \pm 5.76$ & $10.05 \pm 4.68$ \\
\hline & $5 \%$ & $10.74 \pm 5.73$ & $10.40 \pm 4.40$ & $11.24 \pm 4.40$ & $11.17 \pm 5.00$ \\
\hline & $7.5 \%$ & $11.25 \pm 5.90$ & $11.25 \pm 5.03$ & $10.74 \pm 4.41$ & $11.51 \pm 4.63$ \\
\hline
\end{tabular}

Note. $\mathrm{CF}=$ cycle frequency, $\mathrm{PT}=$ poling time, $\mathrm{RPT}=$ relative poling time, $\mathrm{PPF}=$ peak poling force, $\mathrm{APF}=$ average poling force $\mathrm{ACPF}=$ average cycle poling force, $\mathrm{IPF}=$ impulse of poling force

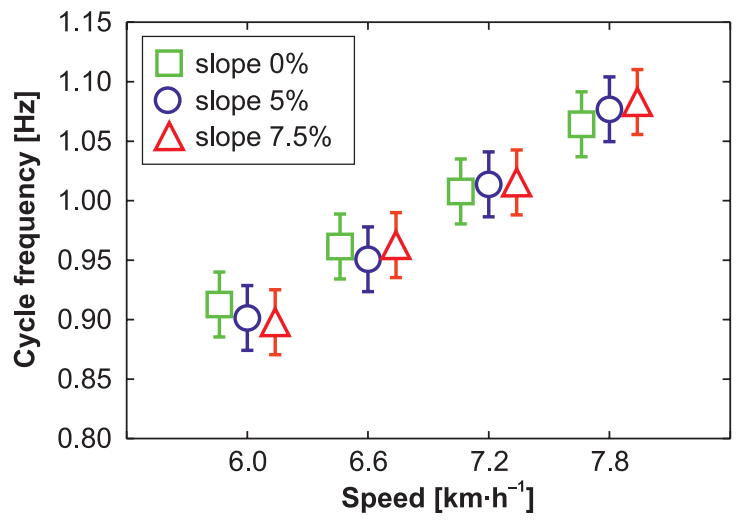

Figure 2. Impact of walking speed on cycle frequency

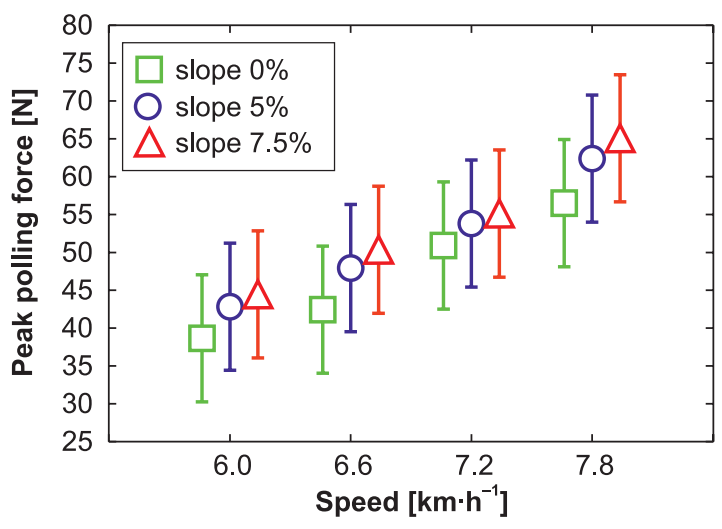

Figure 3. Impact of walking speed on peak poling force 
penditure or perhaps it is directly optimized, based on sensed feedback energy expenditure (Snaterse, Ton, Kuo, \& Donelan, 2011). In our study, cycle frequency kept growing with increasing speed. Based on the claim of authors Egerton, Danoudis, Huxham, and Iansek (2011), Chapman (2008) and Kirtley (2006) we can assume that increase in speed was not only handled by increased cycle frequency but also by extending stride length.

The time indicator of poling time in NW on various types of surface was dealt with by a study by Schiffer et al. (2009). The authors found that poling time is significantly longer on concrete surface then on grass. A study by Schiffer et al. (2011) examined the impact of pole weight on poling time. No significant correlation was found between these variables. In our study, poling time reduced with increase in speed. We also dealt with a question, whether walking speed can impact relative poling time. Nevertheless, this impact was not found.

The study by Hagen et al. (2011) compares the vectors of ground reaction forces caused by axial forces in the poles during the phase of support with a pole, with vectors of ground reaction forces of the lower extremities in the phase of heel strike. When the ground was in horizontal plane, these vectors did not correspond with each other in their direction and there is a slowing down effect of the lower extremity and at the same time there is an accelerating effect caused by applying of the pole, which results in higher load to the lower extremities during the phase of heel strike. On the other hand, directions of reaction force vectors, induced by the pole support during the support phase, more correspond with the vectors of lower extremities' reaction force during the push off. Studies by Willson et al. (2001) and Knight and Caldwell (2000) show increase in stride length when poles are used. We believe that the increase in stride length reduces the angle between the vectors of lower extremities' ground reaction force during the heel strike and the ground itself and thus increases its braking effect. If increasing speed leads to greater braking effect of the lower extremity in the phase of heel strike, it is likely that with higher speed, axial forces in the poles generated by upper extremities will also increase, so that the speed of forward motion is maintained. This fact was confirmed in our study, where peak poling force and average poling force increased with higher velocity.

The number of outputs, dealing with impulse of poling force is not high. A study by Schiffer et al. (2009) examined impact of various types of surface, or more precisely its hardness on impulse of poling force. Correlation between the type of monitored surfaces and the impulse of poling force extent was not shown. The results of our study also show that impulse of poling force did not change significantly with increase in speed. Increase in the forces, acting on the poles, was at increasing speed compensated by reducing the phase of pole support.

\section{Impact of slope}

Change in slope had no significant impact over the above described variables. Nevertheless, in some variables we can find certain trends which are associated with change of slope.

A pilot study by Svoboda, Stejskal, Jakubec, and Krejčí (2011) describes increasing cycle frequency with increasing slope of the ground, upon constant speed $7.6 \mathrm{~km} \cdot \mathrm{h}^{-1}$. Authors describe the increase in cycle frequency upon constant speed by reducing stride length.

On the other hand, a study by Leroux, Fung, and Barbeau (2002) describes an increase in stride length with increasing slope upon constant movement speed. In this study, it was natural walking speed without poles $\left(3.7 \pm 0.68 \mathrm{~km} \cdot \mathrm{h}^{-1}\right)$ on a treadmill, selected by the subjects themselves on the basis of an experiment.

These findings show that at lower walking speed, increase in slope is manifested by reducing cycle frequency and extending stride length while at higher speeds, increase in cycle frequency and reducing stride length occurs with increasing slope.

We also found this trend in our study, where borderline between reducing and increasing cycle frequency occurred at walking speed $6.6 \mathrm{~km} \cdot \mathrm{h}^{-1}$.

Walking up an incline of an increasing slope eventually requires a change in walking pattern. The major change is that the leading foot does not land with the almost straight knee joint seen in horizontal walking. A consequence of this change is that we cannot take advantage of the energy conservation effect seen in horizontal walking. There is needed extra concentric contraction of the hip flexor muscles, which naturally represents extra work and costs us energy. Following lead-foot landing, work is done concentrically by the hip and knee extensors to raise the centre of mass. All of this concentric muscular work gives a continual increase on potential energy (Chapman, 2008). Therefore, there is an assumption that when walking up an incline, greater force must be generated on the poles. On the other hand we believe that when walking up an incline, ground reaction forces vectors induced by axial forces in the poles during the support phase better correspond with ground reaction forces vectors of the lower extremities in the phase of heel strike then when walking on a straight ground. This theory could explain why is there no occurrence of increase in peak poling force, and average poling force, when slope increases. In this case, physical fitness or NW technique could play a role, as we can assume that increasing the force, actuating by the upper extremities, when walking up, would be too demanding for less trained individuals. 
The results can be applied to the activities, which are focused on the load of upper extremities when the poles are used. During NW it is possible to prefer walking speed rather than to change the slope of the ground for those patients, who are indicated to strengthen upper extremities. Similar conclusions apply to training of cross-country skiers during the summer season. In order to verify results, further investigations will be required to describe biomechanical and physiological values during $\mathrm{NW}$ performance.

\section{Limits of the study}

Given the fact that a smaller homogeneous group of subjects, selected on a volunteer basis, was used, these findings cannot be generalised for other professional groups within the population. Walking speed and treadmill slope were firmly set for the entire group, regardless of individuality of a given subject. In order to verify results, further investigations of more complex character will be required.

\section{CONCLUSION}

Change in conditions - walking speed - during NW reflected in changes to spatiotemporal variables and the magnitude of force used by the upper extremities to generate on the poles in the support phase of a stride cycle.

Cycle frequency as well as axial forces transferred to the poles by upper extremities during NW increased with walking speed. Poling time is reduced at the same time. The magnitude of difference in force increase grows with increase of difference in walking speed. However change in slope of the ground had no significant impact over any spatiotemporal and dynamic variables, it is possible to combine walking speed and slope of ground to make different load of upper extremities during NW. Given the comprehensive involvement of the body in NW, when change of walking speed occurs, it is also essential to deal with magnitude of the force produced by upper extremities and the resulting load on the upper extremities. In order to verify these conclusions, further investigations are required to describe relationship between biomechanical and physiological values during $\mathrm{NW}$ performance.

\section{ACKNOWLEDGMENT}

The study has been supported by the internal grant of the Faculty of Physical Culture, Palacký University No. FTK_2013_026.

\section{REFERENCES}

Bohne, M., \& Abendroth-Smith, J. (2007). Effects of hiking downhill using trekking poles while carrying external loads. Medicine \& Science in Sports \& Exercise, 39(1), 177-183.

Chapman, A. E. (2008). Biomechanical analysis of fundamental human movements. Champaign, IL: Human Kinetics.

Egerton, T., Danoudis, M., Huxham, F., \& Iansek, R. (2011). Central gait control mechanisms and the stride length - cadence relationship. Gait \& Posture, 34, 178-182.

Foissac, M. J, Berthollet, R., Seux, J., \& Belli, A. (2008). Effects of hiking pole inertia on energy and muscular costs during uphill walking. Medicine \& Science in Sports \& Exercise, 40(6), 1117-1125.

Hagen, M., Hennig, E. M., \& Stieldorf, P. (2011). Lower and upper extremity loading in nordic walking in comparison with walking and running. Journal of Applied Biomechanics, 27, 22-31.

Hansen, L., Henriksen, M., Larsen, P., \& Alkjaer, T. (2008). Nordic walking does not reduce the loading of the knee joint. Scandinavian Journal of Medicine and Science in Sports, 18, 436-441.

Hansen, E. A., \& Smith, G. (2009). Energy expenditure and comfort during nordic walking with different pole lengths. Journal of Strength and Conditioning Research, 23(4), 1187-1194.

Jakubec, A., Stejskal, P., Svoboda, Z., Krejčí, J., Salinger, J., Štěpaník, P., ... Klimešová, I. (2009). Výzkumný design severské chůze ve světle prvních výsledků [Research design of nordic walking in light of the first results]. Medicina Sportiva Bohemica et Slovaca, 18(4), 189-191.

Kirtley, C. (2006). Clinical gait analysis: Theory and practice. Edinburgh: Elsevier.

Kleindienst, F. I., Michel. K. J., Schwarz, J., \& Krabbe, B. (2006). Comparison of kinematic and kinetic parameters between the locomotion patterns in nordic walking, walking and running [Abstract]. Sportverletz Sportschaden, 20(1), 25-30.

Knight, C. A., \& Caldwell, G. E. (2000). Muscular and metabolic costs of uphill backpacking: Are hiking poles beneficial? Medicine \& Science in Sports \& Exercise, 32(12), 2093-2101.

Kocur, P., Deskur-Śmielecka, E., Wilk, M., \& Dylewicz, P. (2009). Effects of nordic walking training on exercise capacity and fitness in men participating in early, short-term inpatient cardiac rehabilitation after an acute coronary syndrome - a controlled trial. Clinical Rehabilitation, 23(11), 995-1004.

Krejčí, J., Jakubec, A., Pšurný, M., \& Janura, M. (in press). Development and validation of system for measuring poling forces during nordic walking. Acta Universitatis Palackianae Olomucensis. Gymnica. 
Leroux, A., Fung, J., \& Barbeau, H. (2002). Postural adaptation to walking on inclined surfaces: I. Normal strategies. Gait \& Posture, 15, 64-74.

Morgulec-Adamowicz, N., Marszałek, J., \& Jagustyn, P. (2011). Nordic walking - a new form of adapted physical activity (a literature review). Human Movement, 12(2), 124-132.

Riegerová, J. (2007). Severská chůze ve výběru pohybových aktivit pro seniory [Nordic walking in the range of physical activities for elderly citizens]. Česká antropologie, 57, 64-65.

Schiffer, T., Knicker, A., Dannohl, R., \& Strüder, H. K. (2009). Energy cost and pole forces during nordic walking under different surface conditions. Medicine \& Science in Sports \& Exercise, 41(3), 663-668.

Schiffer, T., Knicker, A., Montanarella, M., \& Strüder, H. K. (2011). Mechanical and physiological effects of varying pole weights during nordic walking compared to walking. European Journal of Applied Physiology, 111, 1121-1126.

Schwameder, H., Roithner, R., Müller, E., Niessen, W., \& Raschner, Ch. (1999). Knee joint forces during downhill walking with hiking poles. Journal of Sports Sciences, 17, 969-978.

Snaterse, M., Ton, R., Kuo, A. D., \& Donelan, J. M. (2011). Distinct fast and slow processes contribute to the selection of preferred step frequency during human walking [Abstract]. Journal of Applied Physiology, 110(6), 1682-1690.

Stief, F., Kleindienst, F. I., Wiemeyer, J., Wedel, F., Campe, S., \& Krabbe, B. (2008). Inverse dynamic analysis of the lower extremities during nordic walking, walking, and running. Journal of Applied Biomechanics, 24, 351-359.

Svoboda, Z., Stejskal, P., Jakubec, A., \& Krejčí, J. (2010). Kinematical analysis, pole forces and energy cost of nordic walking. Acta Universitatis Palackianae Olomucensis. Gymnica, 41(2), 27-34.

Willson, J., Torry, M. R., Decker, M. J., Kernozek, T., \& Steadman, J. R. (2001). Effects of walking poles on lower extremity gait mechanics. Medicine \& Science in Sports \& Exercise, 33(1), 142-147.

\section{VLIV RYCHLOSTI CHŮZE A SKLONU TERÉNU NA VELIKOST AXIÁLNÍ SÍLY HOLÍ PŘI SEVERSKÉ CHŮZI \\ (Souhrn anglického textu)}

VÝCHODISKA: Severská chůze se díky své atraktivitě a nenáročnosti na vybavení začíná stále více využivat v oblasti sportu, rekreace a rehabilitace. Některé její vlivy na zatížení organismu nejsou dosud dostatečně prozkoumány.

CÍL: Cílem studie bylo určení vlivu rychlosti pohybu a sklonu podložky na velikost axiálních sil přenášených na hole horními končetinami při severské chůzi.

METODIKA: Studie se účastnilo 17 zdravých probandů ve věku 25,9 $\pm 3,6$ let, kteří absolvovali 12 samostatných měření na běhátku o různých rychlostech $\left(6,0 ; 6,6 ; 7,2\right.$ a $\left.7,8 \mathrm{~km} \cdot \mathrm{h}^{-1}\right)$ a sklonech $(0 ; 5$ a $7,5 \%)$. $\mathrm{Z}$ těchto měření jsme získali hodnoty základních časoprostorových proměnných charakterizujících provedení chůze a silových proměnných působících na hole.

VÝSLEDKY: Zvýšení rychlosti chůze vedlo ke zvýšení frekvence krokového cyklu $(p<0,001)$ a k nárůstu maximální síly fáze opory o hůl a průměrné síly fáze opory o hůl $(p<0,001)$. Doba opory o hůl se s rostoucí rychlostí snížila $(p<0,001)$. Zvýšení sklonu terénu velikost časových a dynamických parametrů významně neovlivnilo.

ZÁVĚR: Zvýšení rychlosti pohybu při severské chůzi zvyšuje velikost síly, kterou působí horní končetiny na hole. Při aplikaci severské chůze u osob (pacientů), u kterých je jedním z cílů terapie také posílení horních končetin, je možné upřednostnit rychlost chůze před změnou náklonu terénu.

Klícová slova: chůze do kopce, horní končetiny, biomechanika, tenzometrický snímač. 